\title{
A retrospective cohort study of adverse events in patients undergoing orthopaedic surgery
}

Joel J. Gagnier ${ }^{1,2^{*}}$, Hal Morgenstern ${ }^{2,3,4}$ and Patrick Kellam ${ }^{5}$

\begin{abstract}
Background: This study's objective was to identify adverse events following common orthopaedic procedures, and to estimate the incidence rates and risks of these events and their associations with age, sex, and comorbidities.

Methods: This retrospective cohort study manually reviewed and extracted electronic medical data on the incidence and predictors of adverse events that occurred within 90 days of the 50 most frequent orthopaedic surgeries at an academic hospital in 2010. We also extracted demographic data, baseline comorbidities, and duration of follow-up ( $\leq 90$ days). Patients were scored on the Charlson Comorbidity Index (CCl) and the Functional Comorbidity Index (FCI). We estimated incidence rates and risks for all events and associations using regression methods. Prolonged pain 42-days post-surgery was treated as a separate outcome.

Results: We included 1,552 patients; average age was 53.4 years, and 51.7\% were female. A total of 1,148 adverse events were identified in 729 patients. The incidence rate of all adverse events was 10 events per 1,000 person-days at risk; 47\% of all patients experienced at least one adverse event within 90 days. The most frequent events were prolonged pain (31\% of all adverse events) and persistent swelling (7\%). We found positive associations between both comorbidity scores and the incidence rate and 90-day risk of all adverse events, excluding pain, adjusting for age and sex (neither of which was associated with adverse events); the association was stronger for the FCl than for the CCl. For total hip arthroplasty (THA) and total knee arthroplasty (TKA), the incidence rate of all adverse events, excluding pain, was positively associated with both comorbidity scores and age; the 90-day risk was positively associate with the $\mathrm{FCl}$ score and male sex. The prevalence of prolonged pain at 42 days was greater in patients with higher $\mathrm{FCl}$ scores; for THA and TKA only, pain prevalence was greater in those with higher FCl scores and in men.
\end{abstract}

Conclusions: Adverse events are frequent following common orthopaedic procedures. The incidence is greatest for patients with more functional comorbidities. For THA and TKA procedures, being male and being older are also associated with a greater incidence of adverse events.

Keywords: Adverse Events, Outcomes, Orthopaedic Surgery, Total Knee Arthroplasty, Total Hip Arthroplasty, Comorbidities

\footnotetext{
* Correspondence: jgagnier@med.umich.edu

'Department of Orthopaedic Surgery, University of Michigan, Ann Arbor, MI, USA

${ }^{2}$ Department of Epidemiology, School of Public Health, University of

Michigan, Ann Arbor, MI, USA

Full list of author information is available at the end of the article
} 


\section{Background}

A large number of adverse events (AE) are encountered during hospitalization, in particular during and after surgical procedures [1-5]. The operating room is a complex environment with a number of factors that increase the risk of AEs [6-12]. In particular, it contains a high concentration of information, can be very fast paced, has many patient transfers, and many person-machine interactions [6, 7]. A recent systematic review of the incidence and nature of in-hospital adverse events found that $58 \%$ of all events were related to surgery with general surgery and orthopaedic surgery being the largest contributors [10]. In addition, some research findings suggest that a large proportion of surgical AEs are preventable (e.g., $[9,10])$. Consequently, several surgical safety mechanisms, including general surgery checklists, have been developed and tested across several surgical disciplines [13-16].

For example, the Surgical Safety Checklist (SSC) [1316] and the SURgical Patient Safety System (SURPASS) checklist were developed $[15,16]$ and both appear to decrease the risk of complications. These results are promising but, these checklists do not specifically address unique characteristics of individual surgical specialties. Several researchers have suggested that surgical safety checklists should be tailored to specific surgical disciplines, institutions, geographic regions and countries [e.g, 13,15]. For example, some healthcare institutions have policies to reduce surgical risk specifically for patients undergoing orthopaedic surgery [17-25].

To determine where surgical safety initiatives need to be modified or focused for relevance to orthopaedic surgery, the incidence and predictors of adverse events must be identified. At this time, however, there is relatively little empirical research on the array of adverse events across the varied types of orthopaedic interventions. Most research focuses on the risk of adverse events following total knee and total hip replacement.

For example, Soohoo et al. [26] found that, following total knee replacement, the 90 -day risk was $0.53 \%$ for mortality, $0.71 \%$ for serious infection, and $0.41 \%$ for pulmonary embolism [26]. They also reported that the overall 90-day risk of a complication (i.e., death, serious infection, pulmonary embolism etc) was positively associated with age, the Charlson Comorbidity Index, hospital volume, having private insurance, being male, and being white. In another study, Pulido et al. [27] reported 12-month infection risks following hip and knee arthroplasty of 0.3 and $1.1 \%$, respectively. Stefansdottir et al. [28] suggested that such infections are closely related to inadequate timing of prophylactic antibiotics. In another study of adverse-event frequency for different orthopaedic procedures, Schilling et al. [29] found a 30 -day mortality risk of $0.005 \%$ for all procedures. They found that hip fracture repair accounted for the greatest share of adverse events (19\%), followed by total knee arthroplasty (18\%), total hip arthroplasty (11\%), and revision total hip arthroplasty (5\%).

More recently, Browne et al. [30] found that across over 200,000 patients who underwent total joint arthroplasty, the following risks of in-hospital postoperative complications were found: anemia $16 \%$, cardiac $0.45 \%$, peripheral vascular $0.1 \%$, respiratory $0.5 \%$, gastrointestinal $0.3 \%$, genitourinary $0.35 \%$, central nervous system $0.1 \%$, hematoma/seroma $0.8 \%$, wound dihescense $0.04 \%$, infection $0.15 \%$, deep vein thrombosis $0.2 \%$, pulmonary embolism $0.1 \%$ and mortality $<0.1 \%$. They also found that Medicaid patients had a higher risk for some of these complications.

While these studies are informative, we could not find any research that comprehensively explored the risk of adverse events across a wide array of orthopaedic procedures. They do not provide a detailed description of all types of adverse events in these patients, such that we can reliably and comprehensively inform safety initiative development. The objectives of this research were to extract data on a broad range of adverse events following orthopaedic surgeries in a hospital population, to estimate and compare the incidence rates and risks of those adverse events, and to assess associations of adverse events with selected patient factors and type of surgery. This information will help inform specific safety system development for this population of patients and in orthopaedic surgery.

\section{Methods}

Study design

We conducted a retrospective cohort study by manually reviewing and extracting from electronic medical records (EMR) data on the incidence and predictors of adverse events that occurred within 90 days for the 50 most frequent orthopaedic surgeries performed at the University of Michigan Health System in 2010. In this project, an adverse event was any negative patient outcome that occurred within 90 days of the patient having surgery and that was described by the investigators a priori or during data collection as possible consequences of surgery or hospitalization.

\section{Data source}

All EMRs were accessed through CareWeb, a web-based clinical patient record system developed for use by clinicians and clinical support staff [31]. We reviewed and extracted data from the orthopaedic clinical notes, notification notes, phone notes, imaging documents and reports. 


\section{Inclusion and exclusion criteria}

We included patients who had an orthopaedic surgical procedure in 2010 for one of the 50 most common Current Procedural Terminology (CPT) codes (See Appendix 1). Patients were excluded if their surgery was a repeat procedure. Patients of any age and with any comorbidites were included.

\section{Data extraction}

One individual (PK) extracted all data into preformatted excel spreadsheets for all included patients. A random sample of approximately ten percent of the first $100 \mathrm{pa}-$ tients was separately and independently reviewed by a second individual (JG) and a third individual, an orthopaedic surgeon, if needed. These individuals then met to discuss any discrepancies in the extraction through discussion and further review of the source EMRs.

First, we extracted demographic information from each patient's EMR including age, sex, primary diagnoses related to the surgery (ICD-9 codes), specific type of surgery (CPT code), comorbidities (ICD-9 codes), and surgeon identification number. Patient names and surgeon names were coded by the data extractor and sent to the investigators to keep them blinded. The codes were kept in a secure location by the data extractor and only referred to by that person when additional data were required.

Adverse events were defined broadly as any of the following: an unintended injury, complication, prolonged hospital stay (greater than 30 days), disability observed at the time of discharge, or death. Unintended injuries or complications included repeat/revision surgery (i.e., due to wrong site surgery, long-term bleeding, nonhealing of wound), surgical site infection, deep vein thrombosis, and the prolonged pain (i.e., 42 days or more of narcotic medication). Appendix 2 lists the adverse events and their definitions used during the data extraction process. We also considered events not predetermined and that were unanticipated but still determined to be possible adverse events by the data extractors (See Appendix 3 for other adverse events). The number of days after the orthopaedic surgical procedure corresponding to each adverse event was also extracted.

Patients were scored on two comorbidity indexes: the Charlson Comorbidity Index (CCI) [32], which was based on the prediction of mortality; and the Functional Comorbidity Index (FCI) [33], which was based on the prediction of functional status. The CCI contains patient data on 19 chronic conditions: acquired immune deficiency syndrome, myocardial infarction, congestive heart failure, peripheral vascular disease, dementia, chronic pulmonary disease, connective tissue disease, peptic ulcer disease, leukemia, lymphoma, tumor without metastasis, metastatic solid tumor, moderate or severe renal disease, cerebrovascular disease, liver disease, and diabetes. Each condition is assigned a weight (an integer from 1 to 6) based on the adjusted association between that condition and the mortality rate in one year (reported by Charlson et al. [32]), and the index score is the sum of the weights for all conditions reported (see Table 3 in Charlson et al. [32]). There is evidence that the CCI predicts outcomes following orthopaedic procedures (e.g., SooHoo et al. [26]).

The FCI was developed by Groll et al. [33] for use in general populations. They derived the FCI from selfreported diagnoses of 18 chronic conditions; the selected conditions predict the physical function subscale (10 items) of the medical outcomes study short form-36 (MOS SF-36). The FCI includes arthritis (osteoarthritis and rheumatoid), osteoporosis, asthma, angina, neurological disease, depression, anxiety or panic disorders, visual impairment, hearing impairment, degenerative disc disease, obesity (body-mass index $>30$ ), chronic obstructive pulmonary disease, congestive heart failure, heart attack, stroke or transient ischemic attack, peripheral vascular disease, diabetes (type I and II), and upper gastrointestinal disease (see Table 5 in Groll et al. [33]). We used one of the recommended methods for scoring the FCI-a simple count of the number of conditions reported by each subject [33]. The FCI includes an important functional assessment that goes beyond the CCI and was developed in patients with musculoskeletal conditions and therefore is appropriate in our population.

\section{Statistical analysis}

First, we described the demographic, surgical, and comorbidity characteristics of patients in the study population. For each type of adverse event (except prolonged pain), we estimated the incidence of that outcome in three ways: the rate of adverse events within the 90-day follow-up period (number of outcome events, divided by total person-time a risk), the 90-day risk (probability of experiencing at least one outcome event during followup); and the mean number of adverse events per procedure. We also calculated the mean number of days from surgery to the first occurrence of each type of event, and we examined the distribution of the number of adverse events per patient (including and excluding prolonged pain). For prolonged pain, we estimated the prevalence at 42 days. Patients lost to follow-up were censored at their last visit.

We used two methods to model the effects of selected variables on the risk or incidence rate of adverse events occurring within 90 days of surgery and the prevalence ratio of prolonged pain at 42 days. In all models, surgeons were treated as random effects using generalized estimating equations. First, modified Poisson regression was used to estimate the crude and adjusted risk ratios 
(RR) for the estimated effects of age, sex, and the CCI or FCI on adverse events within 90 days of surgery; or the prevalence ratio for prolonged pain at 42 days postsurgery. This method was also used to estimate the effects of early adverse events and specific comorbidities on prolonged pain. Second, negative binomial regression was used to estimate the crude and adjusted incidence rate ratios (IRRs) for the effects of age, gender, and the CCI or FCI (and individual comorbidities) on all adverse events occurring in patients during the 90-day follow-up period (i.e., counting all adverse events that occurred in each patient). We analyzed data in all models separately for events related to pain and for those undergoing TKA and THA. We adjusted for follow-up time in all models.

\section{Results}

A total of 6,821 patients were seen in the Department of Orthopaedic Surgery in 2010, of which 1,552 were eligible for this study (see Fig. 1). The average age of all included patients was 53.4 years (range, 2-102); 51.7\% were female. A total of 1,148 adverse events were identified in 729 patients. The mean length of hospital stay was 3.3 days (range $0-62$ ). The proportion of all 1,552 patients that were not followed for at least 90 days after surgery was $34.9 \%(n=541)$; of those not followed for at least 90 days, the mean duration of follow-up was 42.4 days. The rate of adverse events (number of events per total follow-up time) was 0.01 events per day, or 10 events per 1000 days.

Figure 2 shows the 90-day risk of each type of adverse event. The number, proportion and estimated 90-day risk of each type of adverse event as well as the mean number of days post-op for those events among all patients is shown in Table 1. A total of $47 \%$ of all patients experienced at least one adverse event. The most frequent event was prolonged pain, representing $31 \%$ of all adverse events in the study; the 42-day prevalence was $23 \%$. Sepsis, long-term bleeding, and wrong-site surgery had the lowest risks. There was a large number of rare adverse events (31\% of the total) that we grouped together as "other" (see Appendix 2 for a complete list of "other" AEs). Aside from acute loss of blood, most adverse events tended to occur after hospital discharge.

For procedures done at least 15 times in 2010, Table 2 describes the adverse events. Total hip and knee arthroplasty (THA, TKA) were the dominant procedures in this sample. A total of $53 \%$ of all adverse events in the study were in those patients who underwent THA, TKA, or arthrodesis in the lumbar spine. The mean number of AEs per procedure varied appreciably among procedures; it was highest ( $>1 \mathrm{AE} /$ procedure) for application of external fixation system (1.48), lumbar arthrodesis (1.41), open treatment of a femur fracture (1.20), and debridement (1.18).

The adverse events for the top two procedures, THA and TKA are listed in Table 3. For THA other and prolonged pain were by far the most common adverse events (41.9 and 33\% of the total events), followed by draining of wounds (7.3\%). Those undergoing THA did not have any of the following events: hospital stay longer than 30 days, wrong site surgery, long term bleeding, or sepsis. For TKA patients, the most frequent adverse events were prolonged pain (32.1\%) followed by other events (31.7\%) and then persistent swelling (12.8\%), with no patients having a hospital stay longer than 30 days, wrong site surgery, long term bleeding, or sepsis.

Table 4 shows the number and percentage of patients by the number of adverse events per patient, including and excluding prolonged pain. The percentage of all study patients who experienced more than one adverse event during the 90-day follow-up period was $16 \%$ when including prolonged pain and $11 \%$ when excluding prolonged pain.

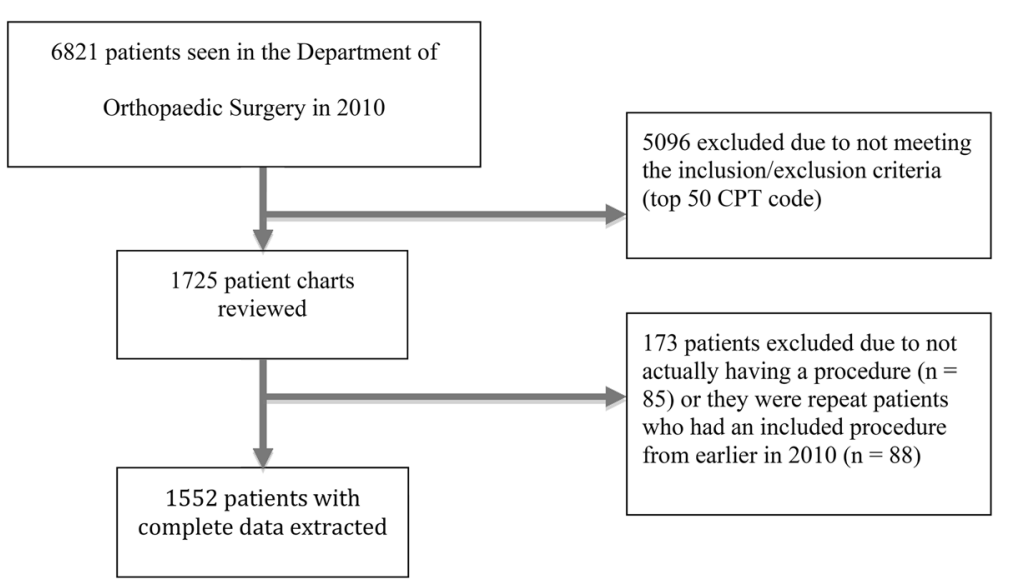

Fig. 1 Patient inclusion flow chart 


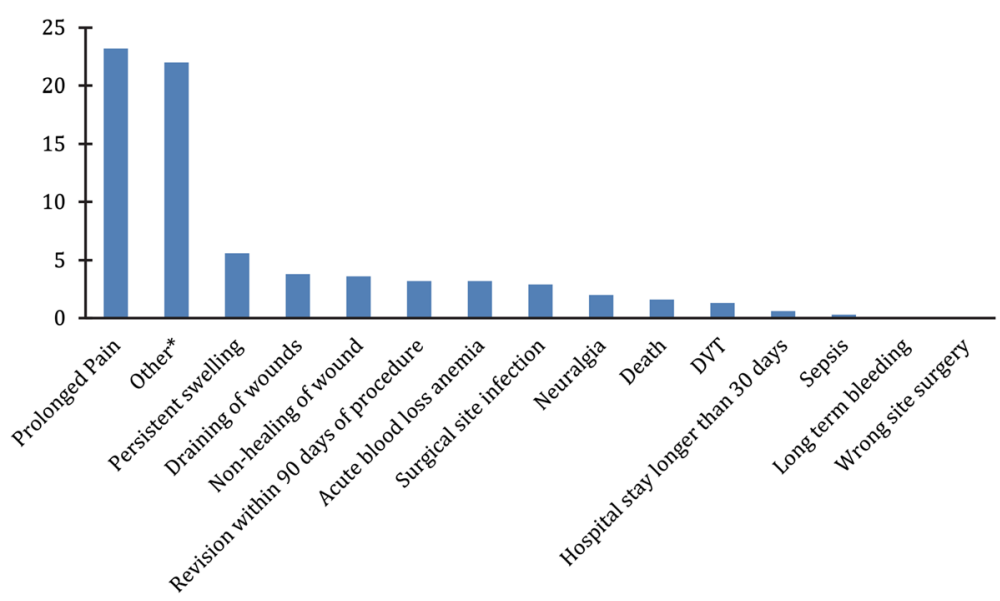

Fig. 2 Ninety-day risk of adverse events across all included patients. *Other adverse events were identified by data extractors during chart review that were not predefined by the investigator. Examples of other adverse events include: urinary tract infection, urinary reten-tion, foot drop, fever, hematoma, pneumonia, bronchitis, myocardial infarction, allergic reaction to medication, hemarthrosis, venous thrombosis, significant blood loss with staple removal, heterotopic ossification

Crude and adjusted incidence rate ratios (IRR) from the negative binomial regression analyses for the rate of adverse events (excluding prolonged pain) are shown in Table 5, separately for all study procedures (Panel A; $N=1192$ ) and for THA and TKA only (Panel B; $N=413$ ). More comorbidity, as measured by both the CCI and FCI scores, was positively associated with the rate of adverse events in the adjusted analyses involving all procedures, but the association was stronger for FCI than for the CCI (adjusted IRR for $\mathrm{FCI}=1.34 ; 95 \% \mathrm{CI}$ : 1.23 to 1.46 ; adjusted IRR for $\mathrm{CCI}=1.20$; 95\% CI: 1.11 to 1.31 ). Both age and sex were unassociated with the rate of adverse events. When restricting the analysis to only TKA and THA procedures, age was positively but weakly associated with the AE rate in both model 1, adjusting for sex and CCI (adjusted IRR per 10 years $=1.15 ; 95 \%$ CI: 1.00 to 1.32 ) and model 2 , adjusting for sex and FCI (adjusted IRR per 10 years $=1.12$; 95\% CI: 0.99 to 1.29$)$.

Table 1 Adverse events across all patients

\begin{tabular}{llll}
\hline Type of Adverse Event & $\begin{array}{l}\text { Number of Events } \\
\text { (percent of total) }\end{array}$ & $\begin{array}{l}\text { 90-Day Event } \\
\text { Risk (\%) }\end{array}$ & $\begin{array}{l}\text { Mean Days from } \\
\text { Surgery to Event }\end{array}$ \\
\hline Prolonged pain $^{\text {a }}$ & $360(31.36)$ & 23.19 & - \\
Persistent swelling & $86(7.40)$ & 5.54 & 50.12 \\
Draining of wounds & $56(4.87)$ & 3.73 & 24.78 \\
Non-healing of wound & $56(4.87)$ & 3.61 & 30.38 \\
Revision within 90 days of procedure & $50(4.36)$ & 3.22 & 40.96 \\
Acute blood loss anemia & $50(4.36)$ & 3.22 & 1.92 \\
Surgical site infection & $44(3.83)$ & 2.84 & 27.09 \\
Neuralgia & $32(2.78)$ & 2.06 & 56.22 \\
Death & $25(2.18)$ & 1.61 & 30.44 \\
DVT & $21(1.83)$ & 1.35 & 21.95 \\
Hospital stay longer than 30 days & $10(0.87)$ & 0.64 & 41.70 \\
Sepsis & $4(0.35)$ & 0.26 & 24.00 \\
Long term bleeding & $2(0.17)$ & 0.13 & 13.00 \\
Wrong site surgery & 0 & 0 & 0 \\
Other & $362(31.53)$ & 23.32 & 17.47 \\
\hline
\end{tabular}

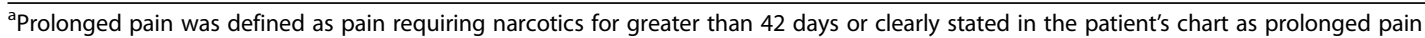
${ }^{b}$ Examples of other adverse events: urinary tract infection, urinary retention, foot drop, fever, hematoma, pneumonia, bronchitis, myocardial infarction, allergic reaction to medication, hemarthrosis, venous thrombosis, significant blood loss with staple removal, heterotopic ossification 
Table 2 Frequency of procedures and adverse events by type of procedure ${ }^{\mathrm{a}}$

\begin{tabular}{|c|c|c|c|c|c|}
\hline Procedure Type & $\begin{array}{l}\text { Number of } \\
\text { Procedures }\end{array}$ & $\begin{array}{l}\text { Percent of all Study } \\
\text { Procedures }\end{array}$ & $\begin{array}{l}\text { Total Number of } \\
\text { Adverse Events }\end{array}$ & $\begin{array}{l}\text { Percent of all } \\
\text { Adverse Events }\end{array}$ & $\begin{array}{l}\text { Mean Number of Events } \\
\text { per Procedure }\end{array}$ \\
\hline Total hip arthroplasty & 313 & 20.17 & 179 & 15.59 & 0.57 \\
\hline Total knee arthroplasty & 252 & 16.24 & 243 & 21.17 & 0.96 \\
\hline Lumbar arthrodesis posterior - single & 132 & 8.51 & 186 & 16.20 & 1.41 \\
\hline Removal of deep implant & 132 & 8.51 & 79 & 6.88 & 0.60 \\
\hline $\begin{array}{l}\text { Open treatment of femur fracture \& } \\
\text { interlocking nail }\end{array}$ & 65 & 4.19 & 78 & 6.79 & 1.20 \\
\hline $\begin{array}{l}\text { Arthroscopy of the knee and partial } \\
\text { menisectomy }\end{array}$ & 64 & 4.12 & 18 & 1.57 & 0.28 \\
\hline $\begin{array}{l}\text { Debridement: skin, tissue, muscle, } \\
\text { bone }\end{array}$ & 60 & 3.87 & 71 & 6.18 & 1.18 \\
\hline $\begin{array}{l}\text { Anterior cruciate ligament repair with } \\
\text { arthroscopy and autograft }\end{array}$ & 53 & 3.41 & 11 & 0.96 & 0.21 \\
\hline $\begin{array}{l}\text { Open treatment femoral fracture } \\
\text { proximal end/neck with fixation }\end{array}$ & 53 & 3.41 & 43 & 3.75 & 0.81 \\
\hline Neurolysis median nerve at carpal T & 38 & 2.45 & 12 & 1.05 & 0.32 \\
\hline $\begin{array}{l}\text { Application of external fixation system, } \\
\text { unilateral; uniplanar }\end{array}$ & 31 & 2.00 & 46 & 4.01 & 1.48 \\
\hline $\begin{array}{l}\text { Slipped capital femoral epiphysis with } \\
\text { femoral neck osteoplasty }\end{array}$ & 31 & 2.00 & 14 & 1.22 & 0.45 \\
\hline $\begin{array}{l}\text { Arthroscopy of shoulder, surgical; with } \\
\text { rotator cuff repair }\end{array}$ & 32 & 2.06 & 12 & 1.05 & 0.38 \\
\hline $\begin{array}{l}\text { Open treatment and fixation of the } \\
\text { clavicle }\end{array}$ & 29 & 1.87 & 14 & 1.22 & 0.48 \\
\hline Gastronemius recession & 29 & 1.87 & 26 & 2.26 & 0.90 \\
\hline Excisional bone biopsy - deep & 25 & 1.61 & 12 & 1.05 & 0.48 \\
\hline $\begin{array}{l}\text { Arthroscopy of the shoulder, surgical; } \\
\text { capsulor repair }\end{array}$ & 24 & 1.55 & 6 & 0.52 & 0.25 \\
\hline $\begin{array}{l}\text { Arthroscopy of the shoulder with } \\
\text { acromioplasty }\end{array}$ & 22 & 1.42 & 8 & 0.70 & 0.36 \\
\hline Arthroscopy, debridge, drill, resect & 17 & 1.10 & 7 & 0.61 & 0.41 \\
\hline Removal of exterior fixator system & 16 & 1.04 & 12 & 1.05 & 0.75 \\
\hline Open toe flexor tenotomy, single & 15 & 0.97 & 8 & 0.70 & 0.53 \\
\hline Other study procedures & 130 & 8.38 & 82 & 0.07 & 0.78 \\
\hline Total study procedures & 1552 & 100 & 1148 & 100 & 0.73 \\
\hline
\end{tabular}

${ }^{\mathrm{a}}$ This table lists only those procedures that were done 15 or more times

Table 6 shows the crude and adjusted associations of age, sex, and CCI or FCI with the 90-day risk of any adverse event (excluding prolonged pain), using modified Poisson regression, for all study procedures (Panel A) and for THA and TKA procedures only (Panel B). In the adjusted analyses for all procedures, increasing FCI and CCI scores were associated with a small increased risk of any AE (adjusted RR for 1 point on the CCI scale = 1.10; $95 \%$ CI: 1.02 to 1.18; and adjusted RR for 1 point on the FCI scale $=1.19,95 \% \mathrm{CI}: 1.13$ to 1.25$)$. Age and sex were minimally associated with the risk of AEs. In the adjusted analysis including only those patients undergoing THA or TKA, men were more likely than women to experience an AE within 90 days (RR adjusting for age and $\mathrm{CCI}=1.22$; $95 \% \mathrm{CI}$ : 0.98 to 1.51 ; $\mathrm{RR}$ adjusting for age and $\mathrm{FCI}=1.23$; $95 \% \mathrm{CI}$ : 1.01 to 1.51). In these restricted analyses, the comorbidity scores were not as strongly associated with AEs as in the analyses of all procedures (adjusted RR for 1 point on the CCI scale $=1.07 ; 95 \%$ CI: 0.99 to 1.15 ; and adjusted RR for 1 point on the FCI scale $=1.13$; 95\% CI: 1.06 to 1.21 ).

Table 7 shows the crude and adjusted prevalence ratios for the associations of age, sex, and CCI or FCI with the 42-day prevalence of prolonged pain, using modified Poisson regression, for all procedures and for THA and TKA procedures only. In the analysis of all procedures, the FCI score was positively associated with the prevalence of prolonged pain at 42 days (adjusted prevalence 
Table 3 Adverse events for total hip or total knee arthroplasty only

\begin{tabular}{llll}
\hline Adverse Event & $\begin{array}{l}\text { Total Hip } \\
\text { Arthroplasty, } \\
N=313 \#(\%)\end{array}$ & $\begin{array}{l}\text { Total Knee } \\
\text { Arthroplasty, }\end{array}$ & Total \\
& $1(0.6)$ & $1(0.4)$ & 2 \\
\hline Death & 0 & 0 & 0 \\
Hospital stay longer than 30 days & & $21(8.6 \%)$ & 28 \\
Revision within 90 days of & $7(3.9)$ & & \\
procedure & & 0 & 0 \\
Wrong site surgery & 0 & $1(0.4)$ & 1 \\
Long term bleeding & 0 & $12(4.9)$ & 16 \\
Non-healing of wound & $4(2.2)$ & $31(12.8)$ & 33 \\
Persistent swelling & $2(1.1)$ & $6(2.5)$ & 13 \\
Surgical site infection & $7(3.9)$ & 0 & 0 \\
Sepsis & 0 & $4(1.6)$ & 17 \\
Draining of wounds & $13(7.3)$ & $1(0.4)$ & 2 \\
DVT & $1(0.6)$ & $78(32.1)$ & 137 \\
Prolonged Pain & $59(33.0)$ & $2(0.8)$ & 6 \\
Nerve Pain & $4(2.2)$ & $8(3.3)$ & 15 \\
Acute Blood Loss Anemia & $7(3.9)$ & $77(31.7)$ & 152 \\
Other & $75(41.9)$ & 243 & 422 \\
Totals & 179 & & \\
\hline
\end{tabular}

ratio $(P R)=1.10 ; 95 \%$ CI: 1.01 to 1.19$)$. Age, sex, and CCI score were only minimally associated with the prolonged pain. In contrast, these results were different for those analyses restricted to THA and TKA procedures. Men were $42 \%$ more likely than women to report prolonged pain at 42 days (PR adjusting for age, sex, and $\mathrm{CCI}=1.42$; $95 \% \mathrm{CI}: 1.09$ to 1.86 ; and PR adjusting for age, sex, and FCI $=1.42$; 95\% CI: $1.10-1.85$ ). There was little association between age and prolonged pain, and the associations between the comorbidity scores and prolonged pain were weaker than observed for other AEs (adjusted PR for 1 point on the CCI scale $=1.02$; 95\% CI: 0.84 to 1.25 ; and adjusted PR for 1 point on the FCI scale $=1.06$; $95 \% \mathrm{CI}: 1.01$ to 1.13 ).

Table 4 Proportion of patients with multiple adverse events

\begin{tabular}{|c|c|c|c|c|}
\hline \multirow{2}{*}{$\begin{array}{l}\text { Number of } \\
\text { Adverse Events }\end{array}$} & \multicolumn{2}{|l|}{ Including Pain } & \multicolumn{2}{|l|}{ Excluding Pain } \\
\hline & $\begin{array}{l}\text { Total Number } \\
\text { of Patients }\end{array}$ & Percentage & $\begin{array}{l}\text { Total Number } \\
\text { of Patients }\end{array}$ & Percentage \\
\hline 0 & 828 & 53.01 & 1050 & 67.22 \\
\hline 1 & 470 & 30.09 & 338 & 21.64 \\
\hline 2 & 160 & 10.24 & 101 & 6.47 \\
\hline 3 & 63 & 4.03 & 42 & 2.69 \\
\hline 4 & 24 & 1.54 & 20 & 1.28 \\
\hline 5 & 11 & 0.70 & 7 & 0.45 \\
\hline 6 & 5 & 0.32 & 4 & 0.26 \\
\hline 7 & 1 & 0.06 & 0 & 0 \\
\hline
\end{tabular}

Using modified Poisson regression, we also examined associations between specific AEs occurring within 42 days of surgery and the prevalence of prolonged pain at 42 days, but the numbers were too small to adjust for covariates. Nevertheless, we found a strong crude association between surgical site infection and prolonged pain (crude PR $=3.59 ; 95 \% \mathrm{CI}$ : 2.22 to 5.80; $p<0.001$ ).

Using negative binomial regression, we also estimated the effects of specific comorbidities on the incidence rate of all AEs (excluding prolonged pain). We found positive associations, adjusting for age, sex and duration of follow-up, for essential hypertension (IRR $=1.45$; 95\% CI: 1.16 to 1.83 ), asthma (IRR $=1.80$; $95 \% \mathrm{CI}: 1.08$ to 3.02 ), and chronic airway obstruction (IRR $=1.81 ; 95 \% \mathrm{CI}: 1.18$ to 2.78). Finally, we examined the relation of asthma and essential hypertension with selected AEs, adjusting for age and sex, using modified Poisson regression. We found that asthma was strongly associated with the prevalence of prolonged pain at 42 days $(\mathrm{PR}=13.3$; $95 \%$ CI: 8.84 to 20.0 ), and it was inversely associated with acute blood loss ( $R R=0.52$; 95\% CI: 0.32 to 0.84$)$.

\section{Discussion}

We found that in patients undergoing the 50 most common orthopaedic procedures at the University of Michigan in 2010, the 90-day risk of having an adverse event after surgery was nearly $50 \%$. These findings are consistent with those of previous studies.

For example, Ouchterlony et al. [34] found that in a sample of 1,361 patients undergoing general, vascular, or orthopaedic surgery, AEs were noted in $47 \%$ of patients in the postoperative unit. In another study of 125,000 Medicare beneficiaries who had undergone unilateral primary TKA and another 11,726 for revision TKA, Mahomed et al. [35] found that within 90 days of the procedure $5.0 \%$ of primary and $10.2 \%$ of revision patients had an $\mathrm{AE}$, as identified through searching for ICD-9 claims codes. These risks are appreciably lower than our estimates (TKA 90 -day risk of 21\%), and this discrepancy likely derives from different definitions of AEs, different methods of identifying the AEs, and different patients populations. In another study, Wolf et al. [36] looked at Medicare beneficiaries who had undergone primary THA $(N=$ $1,405,379)$ and revision THA $(N=337,874)$ between 1991 and 2008. They found a 90-day risk of AEs in the primary THA group of 3.4 to $4.0 \%$ across the study period and for the revision THA group 7.0 to $10.9 \%$ across the study period. Again, these risks were much lower than what we found in our study (THA 90-day risk of 16\%), likely resulting from the differences in definitions of AEs, data extraction methods, and patient populations. Furthermore, we were able to characterize the proportions of specific adverse events in those undergoing THA or TKA (see Table 3), which expands the literature in this area. These 
Table 5 Crude and adjusted associations for age/10, sex, CCl and $\mathrm{FCl}$ with the number of adverse events (excluding pain) across all procedures (Panel A) and for only THA and TKA procedures (Panel B) using negative binomial regression modeling

\begin{tabular}{|c|c|c|c|}
\hline Predictors & Incidence Rate Ratio & $95 \% \mathrm{Cl}$ & $p$-value \\
\hline \multicolumn{4}{|l|}{ A. All Procedures $(N=1192)$} \\
\hline \multicolumn{4}{|l|}{ Crude Associations } \\
\hline Age (decade) & 1.00 & $0.95-1.06$ & 0.87 \\
\hline Sex (male coded as 1) & 0.99 & $0.81-1.21$ & 0.91 \\
\hline CCl score (per 1 point) & 1.20 & $1.11-1.31$ & $<0.001$ \\
\hline FCl score (per 1 point) & 1.34 & $1.23-1.45$ & $<0.001$ \\
\hline \multicolumn{4}{|l|}{ Adjusted Models } \\
\hline \multicolumn{4}{|l|}{ Model 1} \\
\hline Age (decade) & 1.00 & $0.95-1.06$ & 0.92 \\
\hline Sex & 0.99 & $0.81-1.21$ & 0.95 \\
\hline CCl score (per 1 point) & 1.20 & $1.11-1.31$ & $<0.001$ \\
\hline \multicolumn{4}{|l|}{ Model 2} \\
\hline Age (decade) & 0.99 & $0.94-1.04$ & 0.67 \\
\hline Sex & 0.99 & $0.81-1.22$ & 0.97 \\
\hline $\mathrm{FCl}$ score (per 1 point) & 1.34 & $1.23-1.46$ & $<0.001$ \\
\hline \multicolumn{4}{|c|}{ B. THA and TKA Procedures Only $(N=413)$} \\
\hline \multicolumn{4}{|l|}{ Crude Associations } \\
\hline Age (decade) & 1.16 & $1.01-1.33$ & 0.03 \\
\hline Sex & 1.15 & $0.82-1.62$ & 0.41 \\
\hline CCl score (per 1 point) & 1.20 & $1.04-1.39$ & 0.02 \\
\hline FCl score (per 1 point) & 1.24 & $1.09-1.41$ & 0.001 \\
\hline \multicolumn{4}{|l|}{ Adjusted Models } \\
\hline \multicolumn{4}{|l|}{ Model 1} \\
\hline Age (decade) & 1.15 & $1.00-1.32$ & 0.04 \\
\hline Sex & 1.13 & $0.80-1.60$ & 0.47 \\
\hline CCl score (per 1 point) & 1.18 & $1.02-1.37$ & 0.03 \\
\hline \multicolumn{4}{|l|}{ Model 2} \\
\hline Age (decade) & 1.12 & $0.99-1.29$ & 0.08 \\
\hline Sex & 1.16 & $0.82-1.64$ & 0.40 \\
\hline FCl score (per 1 point) & 1.22 & $1.07-1.39$ & $<0.001$ \\
\hline
\end{tabular}

$\mathrm{CCl}$ Charlson comorbidity index, $\mathrm{FCl}$ functional comorbidity index, THA total hip arthroplasty, TKA total knee arthroplasty

latter findings may help orthopaedic surgeons monitor and potentially prevent adverse events in those undergoing total joint arthroplasty.

We found that prolonged pain was by far the most frequent outcome, with a 42-day prevalence of $23 \%$ across all procedures and $28.7 \%$ in patients undergoing THA and $20.0 \%$ in patients undergoing TKA. Other researchers have looked at pain in patients undergoing total joint arthroplasty. For example, in one study of THA and TKA patients, Carroll et al. [37]) found that
Table 6 Crude and adjusted associations for age/10, sex, CCl and $\mathrm{FCl}$ with the 90-day risk of an adverse event (excluding pain) across all procedures (Panel A) and for only THA and TKA procedures (Panel B) using modified Poisson regression modeling

\begin{tabular}{llll}
\hline Predictors & Risk Ratio & $95 \% \mathrm{Cl}$ & $p$-value \\
\hline $\begin{array}{l}\text { Panel A: All Procedures (N=1192) } \\
\text { Crude Associations }\end{array}$ & 1.03 & $0.99-1.07$ & 0.12 \\
$\quad$ Age (decade) & 1.02 & $0.81-1.29$ & 0.85 \\
Sex & 1.10 & $1.02-1.18$ & 0.01 \\
CCl score (per 1 point) & 1.19 & $1.13-1.25$ & $<0.001$ \\
FCl score (per 1 point) & & & \\
Adjusted Models & & & \\
Model 1 & 1.03 & $0.99-1.07$ & 0.13 \\
Age (decade) & 1.04 & $0.82-1.30$ & 0.76 \\
Sex & 1.10 & $1.01-1.18$ & 0.02 \\
CCl score (per 1 point) & & & \\
Model 2 & 1.02 & $0.98-1.06$ & 0.28 \\
Age (decade) & 1.03 & $0.82-1.30$ & 0.80 \\
Sex & 1.19 & $1.13-1.25$ & $<0.001$ \\
FCl score (per 1 point) &
\end{tabular}

Panel B: THA and TKA Procedures Only $(N=413)$

Crude Associations

$\begin{array}{llll}\text { Age (decade) } & 1.12 & 0.96-1.31 & 0.15 \\ \text { Sex } & 1.23 & 1.01-1.50 & 0.04 \\ \text { CCl score (per 1 point) } & 1.09 & 0.98-1.20 & 0.104 \\ \text { FCl score (per 1 point) } & 1.14 & 1.07-1.22 & <0.001\end{array}$

Adjusted Models

Model 1

$\begin{array}{llll}\text { Age (decade) } & 1.12 & 0.97-1.28 & 0.12 \\ \text { Sex } & 1.22 & 0.98-1.51 & 0.07 \\ \text { CCl score (per 1 point) } & 1.07 & 0.99-1.15 & 0.07\end{array}$

Model 2

$\begin{array}{llll}\text { Age (decade) } & 1.11 & 0.96-1.27 & 0.16 \\ \text { Sex } & 1.23 & 1.01-1.51 & 0.04 \\ \text { FCl score (per 1 point) } & 1.13 & 1.06-1.21 & <0.001\end{array}$

1. For the variable sex, female was coded as a 0 and male as a 1 $\mathrm{CCl}$ Charlson comorbidity index, $\mathrm{FCl}$ functional comorbidity index, THA total hip arthroplasty, TKA total knee arthroplasty

the median time to pain resolution was 81 days (95\% CI: 49 to 146 days) in TKA patients and 81 days (95\% CI: 43 to 146 days) in THA patients. While the outcome used in their study is different than ours, their findings indicate that more than $50 \%$ of patients in their sample would have had prolonged pain as defined in our project, because the median time to pain resolution was greater than 42 days in both THA and TKA patients. The higher proportion of patients with prolonged pain is not surprising, given that they defined pain differently. 
Table 7 Crude and adjusted associations for age/10, sex, CCl and $\mathrm{FCl}$ with the adverse event of pain or not at 42 days across all procedures (Panel A) and for only THA and TKA procedures (Panel B) using modified Poisson regression modeling

\begin{tabular}{llll}
\hline Predictors & Prevalence Ratio & $95 \% \mathrm{Cl}$ & $p$-value \\
\hline $\begin{array}{l}\text { Panel A: All Procedures (N=1552) } \\
\text { Crude Associations }\end{array}$ & & & \\
$\quad$ Age (decade) & 1.02 & $0.97-1.08$ & 0.36 \\
Sex & 0.85 & $0.68-1.05$ & 0.13 \\
CCl score (per 1 point) & 1.02 & $0.88-1.19$ & 0.77 \\
FCl score (per 1 point) & 1.10 & $1.02-1.20$ & 0.02 \\
Adjusted Models & & & \\
Model 1 & & & \\
Age (decade) & 1.02 & $0.97-1.08$ & 0.38 \\
Sex & 0.85 & $0.68-1.05$ & 0.14 \\
CCl score (per 1 point) & 1.02 & $0.87-1.20$ & 0.81 \\
Model 2 & & & \\
Age (decade) & 1.02 & $0.97-1.07$ & 0.46 \\
Sex & 0.85 & $0.68-1.06$ & 0.16 \\
FCl score (per 1 point) & 1.10 & $1.01-1.19$ & 0.03
\end{tabular}

Panel B THA and TKA Procedures Only $(N=550)$

Crude Associations

$\begin{array}{llll}\text { Age (decade) } & 0.98 & 0.92-1.05 & 0.57 \\ \text { Sex } & 1.42 & 1.10-1.85 & 0.01 \\ \text { CCl score (per 1 point) } & 1.03 & 0.86-1.24 & 0.76 \\ \text { FCl score (per 1 point) } & 1.06 & 1.01-1.12 & 0.03\end{array}$

Adjusted Models

Model 1

$\begin{array}{llll}\text { Age (decade) } & 0.98 & 0.91-1.06 & 0.68 \\ \text { Sex } & 1.42 & 1.09-1.86 & 0.01 \\ \text { CCl score (per 1 point) } & 1.02 & 0.84-1.25 & 0.82 \\ \text { Model 2 } & & & \\ \text { Age (decade) } & 0.98 & 0.91-1.05 & 0.56 \\ \text { Sex } & 1.42 & 1.10-1.85 & 0.01 \\ \text { FCl score (per 1 point) } & 1.06 & 1.01-1.13 & 0.03\end{array}$

1. For the variable sex, female was coded as a 0 and male as a 1 $\mathrm{CCl}$ Charlson comorbidity index, $\mathrm{FCl}$ functional comorbidity index, THA total hip arthroplasty, TKA total knee arthroplasty

Carroll et al. defined pain as any type of pain included in the Brief Pain Inventory (BPI), which includes a variety of questions on the person's perception of pain.

We found that the mean number adverse events was greatest for lumbar spinal surgery and fixation of an external fixation system. These findings are not surprising, given that these procedures are considerably invasive, the latter of which resulting from trauma. Other investigators have found a very similar frequency of adverse events following spinal surgery (e.g., Hellsten et al. [38]) and that trauma patients have higher risks of complications [39]. For example, a recent analysis of $\mathrm{Na}$ tional Surgical Quality Improvement Program (NSQIP) data on 146,773 orthopaedic patients (22,361 trauma patients) found that trauma patients had a higher risk of complications [39].

Across all of our adjusted regression models the FCI positively predicted the incidence of all adverse events, and the strength of that association was consistently greater than for the CCI. Given that the FCI was developed to predict function, its predictive capability for AEs in this population of orthopaedic patients was expected. To our knowledge, our study is the first to show the association between the FCI and adverse events following orthopaedic surgery. In our models for THA and TKA only, being older predicted an increased rate of AEs and being male increased the risk of any AE. Other research in patients undergoing revision THA and TKA showed an increased risk for AEs in older patients and in men $[35,40]$.

In our adjusted regression models, we found that essential hypertension, asthma and chronic airway obstruction were positively associated with the rate of all AEs within 90 days of an orthopaedic procedure. When we examined these relations further, we found that asthma was strongly and positively associated with the 42-day prevalence of prolonged pain and inversely associated with the risk of acute blood loss. The relation between individual comorbidities and AEs has been explored in other research. For example, Minhas et al. [41], using data from the NSQIP database on 42,150 patients, explored the relation of a number of variables on the occurrence of a cerebral vascular accident (CVA) following an orthopaedic procedure and reported in their adjusted analysis that hypertension, dyspnea and chronic obstructive pulmonary disease (COPD) were strongly associated with CVAs. But they also found that insulin dependent diabetes mellitus and a history of a transient ischemic attack predicted CVAs as well. While we found that diabetes mellitus predicted individual and multiple AEs in our crude models, when adjusted for age sex and other comorbidities, the relation was eliminated. Of course, in our study we looked across all AEs, not just CVAs. Other research on the risk of AEs in TKA patients while hospitalized, also failed to show an association between diabetes and the risk of AEs, but did find that COPD strongly predicted the risk of AEs [42]. To the best of our knowledge, the relation we found between asthma and the 42-day prevalence of prolonged pain has not been reported elsewhere. Future rigorous research is required to confirm this finding.

Our study has several strengths. We included a sample of all patients undergoing the top 50 orthopaedic procedures at a large academic center. Therefore, we expect our findings to be generalizable to orthopaedic patients 
undergoing the same procedures at other academic centers. We extracted a large amount of data from patient charts and considered the most practical approach for identifying AEs in a large number of patients following surgical procedures [43]. Furthermore, we were careful to be certain that extractions were cross-checked. Thus, we are confident that our data extraction was complete and reliable. In addition, we extracted a large selection of potential AEs, which goes beyond what has been done in other research. Furthermore, we performed many careful analyses, attempting to delineate associations so as to inform further research in the area.

One potential drawback of our study is that the generalizability does not necessarily extend beyond academic centers or to procedures not included in our analyses. Furthermore, it is possible that the charts in the EMR for each patient may suffer from unclear or underreporting of AEs (reporting bias), resulting in biased estimates of rates and risks in this study. For example, it is possible that certain procedures or conditions may cause attending physicians to look harder for potential adverse events or chart them more frequently for those patients, resulting in detection bias. The role of reporting bias and detection biases as it relates to chart reviews of AEs should be explored further. Another potential drawback of our study is that almost $35 \%$ of the included patients had less than 90 days of followup and a mean follow-up of approximately 42 days. The lack of complete follow-up in these patients could have biased our findings; thus, caution is advised when interpreting our findings. Finally, because we did not compare the incidence of outcome events in surgical vs. non-surgical patients, we cannot make any inferences about the effects of surgery or hospitalization on the occurrence of adverse events in this study; i.e., the adverse events were not necessarily caused by the patients' surgery or hospitalization that preceded them.

\section{Conclusion}

We found that patients undergoing orthopaedic procedures are likely to experience a broad spectrum of adverse events. Some of those events have serious implications to the patient's health, whereas many others are temporary or can easily be treated. Indeed, the types of AEs considered in this study are broader than the types of events described in previous studies. We also found that certain patient characteristics, especially comorbidities, are associated with the incidence of adverse events. These findings may aid clinicians in identifying which patients are at an increased risk for certain AEs. We feel that these findings support the need for large prospective (possibly randomized) studies, with careful patient follow-up to delineate the risk of particular AEs and to assess which AEs are in fact affected by orthopaedic procedures.

\section{Appendix 1}

Table 8 CPT Code Descriptions and Volume

\begin{tabular}{|c|c|c|}
\hline CPT Code & Procedure Description & Volume \\
\hline 20610 & ASPIRATE OR INJECT MAJOR JOINT 13 & 5 \\
\hline 20610 & ASPIRATE OR INJECT MAJOR JOINT & 3,704 \\
\hline 20610 & ASPIRATE/INJECT MAJOR JOINT & 14 \\
\hline 20610 Total & & 3,723 \\
\hline 20680 & REMOVAL OF IMPLANT - DEEP 13 & 178 \\
\hline 20680 & REMOVAL OF IMPLANT - DEEP & 342 \\
\hline 20680 Total & & 520 \\
\hline 29881 & ARTHROSCOPY,KNEE \& PART MENISECTOMY & 270 \\
\hline 29881 & ARTHROSCOPY,KNEE \& PART MENISECTOMY & 83 \\
\hline 29881 Total & & 353 \\
\hline 27130 & TOTAL HIP ARTHROPLASTY & 341 \\
\hline 27130 & TOTAL HIP REPLACE W CALCAR & 6 \\
\hline 27130 Total & & 347 \\
\hline 29826 & ARTHROSCOPY SHOULDER W ACROMIOPLASTY & 184 \\
\hline 29826 & ARTHROSCOPY SHOULDER W/ACROMIOPLASTY & 108 \\
\hline 29826 Total & & 292 \\
\hline 27447 & TOT KNEE ARTHROPLASTY-MED \& LATERAL & 281 \\
\hline 27447 & TOT KNEE ARTHROPLASTY-MED \& LATERAL 13 & 5 \\
\hline 27447 Total & & 286 \\
\hline 29888 & ARTHROSCOPIC ACL RECONSTRUCTION & 4 \\
\hline 29888 & ARTHROSCOPIC ACL RECONSTRUCTION & 32 \\
\hline 29888 & ACL REPAIR W ARTHROSCOPE AND AUTOGRAFT 13 & 1 \\
\hline 29888 & ACL REPAIR W ARTHROSCOPE AND AUTOGRAFT & 215 \\
\hline 29888 Total & & 252 \\
\hline 29822 & ARTHROSCOPY,SHOULDER,SURGICAL;LIMIT 13 & 223 \\
\hline 29822 & ARTHROSCOPY,SHOULDER,SURGICAL;LIMIT & 7 \\
\hline 29822 Total & & 230 \\
\hline 20605 & ASPIRATE OR INJECT INTERMED JOINT 13 & 3 \\
\hline 20605 & ASPIRATE OR INJECT INTERMED JOINT & 205 \\
\hline 20605 Total & & 208 \\
\hline 22614 & FUSION POSTR EA ADD SEG & 193 \\
\hline 22614 Total & & 193 \\
\hline 29827 & $\begin{array}{l}\text { ARTHROSCOPY,SHOULDER,SURGICL; W ROTATR } \\
\text { CUFF REPAIR }\end{array}$ & 170 \\
\hline 29827 & $\begin{array}{l}\text { ARTHROSCOPY,SHOULDR,SURGICL;W ROTATR } \\
\text { CUFF REPAIR }\end{array}$ & 3 \\
\hline 29827 Total & & 173 \\
\hline 29877 & ARTHROSCOPY,DEBRIDGE,DRILL, RESECT & 120 \\
\hline 29877 & ARTHROSCOPY,DEBRIDGE,DRILL,RESECT & 52 \\
\hline 29877 Total & & 172 \\
\hline 29450 & APPLICA CLUBFOOT CAST UNILATERAL & 159 \\
\hline 29450 & APPLIC CLUBFOOT CAST UNILATERAL & 2 \\
\hline 29450 & APPLICA CLUBFOOT CAST UNILATERAL 13 & 1 \\
\hline 29450 Total & & 162 \\
\hline 20936 & AUTOGRAFT FOR SPINE SURG ONLY,LOC THRU & 160 \\
\hline
\end{tabular}


Table 8 CPT Code Descriptions and Volume (Continued)

\begin{tabular}{|c|c|}
\hline \multicolumn{2}{|c|}{20936 Total } \\
\hline 64721 & NEUROLYSIS MEDIAN NERVE AT CARPAL T 13 \\
\hline 64721 & NEUROLYSIS MEDIAN NERVE AT CARPAL T \\
\hline \multicolumn{2}{|c|}{64721 Total } \\
\hline 26055 & TENDON SHEATH INCISION-TRIGGER FING \\
\hline 26055 & TENDON SHEATH INCISION-TRIGGER FING 13 \\
\hline \multicolumn{2}{|c|}{26055 Total } \\
\hline 20930 & $\begin{array}{l}\text { MORSELIZED ALLOGRAFT, FOR SPINE } \\
\text { SURGRY;LIST SEP IN ADDITN }\end{array}$ \\
\hline \multicolumn{2}{|c|}{20930 Total } \\
\hline 22843 & POSTR INSTRU 7 - 12 SEGMENTS; LIST SEPAR \\
\hline \multicolumn{2}{|c|}{22843 Total } \\
\hline 11012 & DEBRIDE: SKIN, TISSUE, MUSCLE, BONE 13 \\
\hline 11012 & DEBRIDE: SKIN, TISSUE, MUSCLE, BONE 13 \\
\hline \multicolumn{2}{|c|}{11012 Total } \\
\hline 22849 & REINSERTION SPINAL FIXATION DEVICE \\
\hline 22849 & REINSERTION SPINAL FIXATION DEVICE \\
\hline \multicolumn{2}{|c|}{22849 Total } \\
\hline 25500 & TX RADIUS SHAFT FRACTURE W/O MANIPU 13 \\
\hline 25500 & TX RADIUS SHAFT FRACTURE W/O MANIPU \\
\hline \multicolumn{2}{|c|}{25500 Total } \\
\hline 22612 & ARTHRODESIS POSTERIOR LUMBAR-SINGLE \\
\hline \multicolumn{2}{|c|}{22612 Total } \\
\hline 29405 & APPLICATION OF SHORT LEG CAST \\
\hline 29405 & APPLICATION/SHORT LEG CAST \\
\hline \multicolumn{2}{|c|}{29405 Total } \\
\hline 29875 & ARTHROSCOPY \& PLICA\&/OR SHELF RESECT \\
\hline 29875 & ARTHROSCOPY \&PLICA\&/OR SHELF RESECT \\
\hline \multicolumn{2}{|c|}{29875 Total } \\
\hline 29806 & ARTHROSCOPY,SHOULDER,SURG,CAPSULORRH \\
\hline 29806 & ARTHROSCOPY,SHOULDER,SURG; CAPSULORRH \\
\hline \multicolumn{2}{|c|}{29806 Total } \\
\hline 20550 & INJECT SINGL TENDON SHEATH OR LIGAMENT \\
\hline 20550 & INJECT SINGL TENDON SHEATH OR LIGAM \\
\hline \multicolumn{2}{|c|}{20550 Total } \\
\hline 22842 & POSTERIOR INSTRUMENTATION-SEPARATE LISTING \\
\hline \multicolumn{2}{|c|}{22842 Total } \\
\hline 22802 & ARTHRODESIS-7 OR MORE VERTEBRAE \& GRAFT \\
\hline 22802 & ARTHRODESIS-7 OR MORE VERTEBRAE W GRAFT \\
\hline \multicolumn{2}{|c|}{22802 Total } \\
\hline 28232 & OPEN TOE FLEXOR TENOTOMY SINGLE \\
\hline 28232 & OPEN TOE FLEXOR TENOTOMY SINGLE 13 \\
\hline \multicolumn{2}{|c|}{28232 Total } \\
\hline 27179 & OR SCFE W/FEMORAL NECK OSTEOPLASTY 13 \\
\hline 27179 & OR SCFE W/FEMORAL NECK OSTEOPLASTY \\
\hline \multicolumn{2}{|c|}{27179 Total } \\
\hline 29075 & APPLICATION SHORT ARM CAST (OSA) \\
\hline 29075 & APPLICAT SHORT ARM CAST \\
\hline
\end{tabular}

Table 8 CPT Code Descriptions and Volume (Continued)

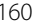

17

139

156

100


Table 8 CPT Code Descriptions and Volume (Continued)

\begin{tabular}{|c|c|c|}
\hline 29824 Total & & 59 \\
\hline 63048 & LAMINECTOMY, EA ADDTL SEGMENT 13 & 59 \\
\hline 63048 Total & & 59 \\
\hline 20245 & EXCISIONAL BONE BIOPSY - DEEP (OSA) 13 & 46 \\
\hline 20245 & EXCISIONAL BONE BIOPSY - DEEP (OSA) & 12 \\
\hline 20245 Total & & 58 \\
\hline 27236 & OPEN TX FEM FX PROX END/NECK W/FIX & 54 \\
\hline 27236 & OPEN TX FEM FX PROX END/NECK W/FIX 13 & 3 \\
\hline 27236 Total & & 57 \\
\hline 22310 & TRTMT VERT BODY FX W/O MANIP & 56 \\
\hline 22310 Total & & 56 \\
\hline 23515 & OPEN TX FX CLAVICLE(INCL FIXATN WHEN PERF) & 54 \\
\hline 23515 & OPEN TX FX CLAMCLE INCL FIXN WHEN PERFORMD & 1 \\
\hline 23515 Total & & 55 \\
\hline 27687 & GASTRONEMIUS RECESSION(EG,STRAYER) & 37 \\
\hline 27687 & GASTRONEMIUS RECESSION(EG,STRAYER) & 17 \\
\hline 27687 Total & & 54 \\
\hline 27792 & $\begin{array}{l}\text { OPEN TX LATERAL MALLEOLUS FX INCLD INT } \\
\text { FIXN IF PERFORMED }\end{array}$ & 49 \\
\hline 27792 & $\begin{array}{l}\text { OPEN TX LATERAL MALLEOLUS FX INCL INTRN } \\
\text { FIX WHEN PERFORMD }\end{array}$ & 5 \\
\hline
\end{tabular}

\section{Appendix 2}

Table 9 Adverse event list and definitions/source

\begin{tabular}{ll}
\hline Adverse Event & Definition \\
\hline Death & Reported in EHR \\
Hospital stay longer than 30 days & Reported in EHR \\
Revision within 90 days of & Reported in EHR \\
procedure & \\
Wrong site surgery & Reported as such in EHR \\
Long-term bleeding & Reported as such in EHR \\
Non-healing of wound & Reported as such in EHR \\
Persistent swelling & Reported as such in EHR \\
Surgical site infection & Reported as such in EHR \\
Sepsis & Reported as such in EHR \\
Persistent Draining of wounds & Reported as such in EHR \\
Deep Vein Thrombosis & Reported as such in EHR \\
Prolonged Pain & Greater than 42 days on narcotics or \\
reported in EHR \\
Nerve Pain \\
Additional Medication Required \\
Acute Blood Loss/Anemia \\
Other
\end{tabular}

${ }^{a}$ Musculoskeletal, non-union, urinary retention, urinary tract infection, gastrointestinal, foot drop, intra-operative complications, cranial/ cerebral, pulmonary, re-injury, neuronal, hematoma, cardiac, reactions limb discrepancy, hematological, hematuria, integumentary, seromas, renal, chest pain

\section{Appendix 3}

Table 10 Other Adverse Events

\begin{tabular}{|c|c|c|c|}
\hline Event Category & Number & $\begin{array}{l}\text { Mean Days } \\
\text { Post-Op }(95 \% \text { Cl) }\end{array}$ & Actual Events \\
\hline Musculoskeletal & 18 & $\begin{array}{l}42.72 \\
(12.94-29.78)\end{array}$ & $\begin{array}{l}\text { Bone ulcer, bursitis, } \\
\text { post-op weakness, } \\
\text { tendonitis, hemarthrosis, } \\
\text { paresis, back spasms, } \\
\text { tendon dysfunction, }\end{array}$ \\
\hline $\begin{array}{l}\text { Non-union of a } \\
\text { fracture }\end{array}$ & 1 & 64 & N/A \\
\hline Urinary retention & 17 & $\begin{array}{l}22.88 \\
(0-46.70)\end{array}$ & N/A \\
\hline Gastrointestinal & 35 & $\begin{array}{l}15.03 \\
(10.77-19.29)\end{array}$ & $\begin{array}{l}\text { Esophagitis, } \\
\text { emphysematous gastritis }\end{array}$ \\
\hline
\end{tabular}

bloody stool, Gl bleed, bowel obstruction,

$\mathrm{G}$ tube infection, diarrhea, constipation, ileus, GI stress, C. Diff, acute colonic pseudo obstruction, continued nausea/vomit, acute on chronic vascular insufficiency of the bowel, PEG tube, Dobhoff tube falling out, viral gastroenteritis, dysphagea, dehydration, enema, colonic distention

\begin{tabular}{|c|c|c|c|}
\hline $\begin{array}{l}\text { Urinary tract } \\
\text { infection }\end{array}$ & 49 & $\begin{array}{l}12.20 \\
(8.46-15.95)\end{array}$ & N/A \\
\hline Foot drop & 7 & $\begin{array}{l}20.14 \\
(2.61-37.68)\end{array}$ & N/A \\
\hline $\begin{array}{l}\text { Intra-op } \\
\text { complications }\end{array}$ & 24 & 0 & $\begin{array}{l}\text { Seizure, severe bleeding } \\
\text { after tornequet removed, } \\
\text { partial avulsion fxs, Pt } \\
\text { awake during surgery, } \\
\text { latrogentic fxs, broken } \\
\text { retained needle, vessels } \\
\text { and arteries encountered, } \\
\text { inferomedial neck fx, } \\
\text { dural tear, retained drain } \\
\text { tip, difficult intubation } \\
\text { resulting in chipped } \\
\text { tooth, tibial tubericle } \\
\text { avulsion fx, peri-op } \\
\text { NSTEMI, biceps tendon } \\
\text { tear, ST elevation, failed } \\
\text { sending of specimen } \\
\text { from OR }\end{array}$ \\
\hline $\begin{array}{l}\text { Psychological/ } \\
\text { cranial/cerebral }\end{array}$ & 24 & $\begin{array}{l}11.38 \\
(4.54-18.21)\end{array}$ & $\begin{array}{l}\text { disoriented, oversedation, } \\
\text { syncopal episode, } \\
\text { somnolence, delerium, } \\
\text { double vision, non- } \\
\text { convulsive status, altered } \\
\text { mental status, TIAs, } \\
\text { postop confusion, anoxic } \\
\text { brain injury, gabapentin } \\
\text { toxocity w/altered mental } \\
\text { status, presyncope drug } \\
\text { overdose, sleeping } \\
\text { problems, withdrawl } \\
\text { symptoms }\end{array}$ \\
\hline
\end{tabular}


Table 10 Other Adverse Events (Continued)

\begin{tabular}{|c|c|c|c|}
\hline Pulmonary & 50 & $\begin{array}{l}14.30 \\
(10.71-17.89)\end{array}$ & $\begin{array}{l}\text { hypercarbia, } \mathrm{O} 2 \\
\text { dependence, respiratory } \\
\text { arrest, hypercarbic resp } \\
\text { failure, pneumothorax, } \\
\text { dyspnea, Pes }\end{array}$ \\
\hline Re-injury & 10 & $\begin{array}{l}30.70 \\
(12.82-48.58)\end{array}$ & $\begin{array}{l}\text { dislocations, screws } \\
\text { backing out, re-fracturing, } \\
\text { dural tears post-op }\end{array}$ \\
\hline Neuronal & 16 & $\begin{array}{l}57.88 \\
(45.22-70.53)\end{array}$ & $\begin{array}{l}\text { Nerve palsy, dysesthesia, } \\
\text { numbness, weakness, } \\
\text { paresis in BLE, mild } \\
\text { dyskinesia, back spasms }\end{array}$ \\
\hline Hematoma & 13 & $\begin{array}{l}14.77 \\
(9.49-20.04)\end{array}$ & $\mathrm{N} / \mathrm{A}$ \\
\hline Cardiac & 29 & $\begin{array}{l}5.90 \\
(2.55-9.24)\end{array}$ & $\begin{array}{l}\text { Afib, hypotension, } \\
\text { venous congestion, } \\
\text { asymp tachycardia, desat, } \\
\text { cardiac arrest, } \\
\text { hypertension, angina, } \\
\text { post-op hypotension, } \\
\text { PEA bradycardia rhythm, } \\
\text { junctional arrhythemia, } \\
\text { ischemia, myocardial } \\
\text { infarction, hypoxia }\end{array}$ \\
\hline $\begin{array}{l}\text { Allergic or } \\
\text { treatment } \\
\text { reactions }\end{array}$ & 17 & $\begin{array}{l}15.71 \\
(7.37-24.04)\end{array}$ & $\begin{array}{l}\text { Allergic, blood transfusion, } \\
\text { vomitting on narcs, } \\
\text { anaphylaxis, staple } \\
\text { reactions, increased INR }\end{array}$ \\
\hline $\begin{array}{l}\text { Limb-length } \\
\text { discrepancy }\end{array}$ & 3 & $\begin{array}{l}44.67 \\
(7.13-24.04)\end{array}$ & $\mathrm{N} / \mathrm{A}$ \\
\hline Hematological & 8 & $\begin{array}{l}7.38 \\
(3.38-11.37)\end{array}$ & $\begin{array}{l}\text { epistaxis, superficial VT, } \\
\text { thrombocytosis, } \\
\text { bacteremia, TIA, } \\
\text { hyponatremia increased } \\
\text { blood glucose, chronic } \\
\text { vascular insufficiency }\end{array}$ \\
\hline Hematuria & 3 & $\begin{array}{l}13 \\
(0-33.01)\end{array}$ & $\mathrm{N} / \mathrm{A}$ \\
\hline Integumentary & 28 & $\begin{array}{l}30.54 \\
(22.44-38.63)\end{array}$ & $\begin{array}{l}\text { Suture sinus, furuncle, } \\
\text { blood blister, fracture } \\
\text { blister, retained sutures }\end{array}$ \\
\hline Seromas & 4 & $\begin{array}{l}22.75 \\
(4.89-40.61)\end{array}$ & N/A \\
\hline Renal & 5 & $\begin{array}{l}2.20 \\
(0-4.38)\end{array}$ & $\begin{array}{l}\text { Acute on chronic renal } \\
\text { failure, postop acute } \\
\text { renal failure, renal failure }\end{array}$ \\
\hline Chest Pain & 2 & $\begin{array}{l}44.50 \\
(0-102.02)\end{array}$ & N/A \\
\hline
\end{tabular}

\section{Abbreviations}

AEs: Adverse events; CCl: Charlson comorbidity index; Cl: Confidence interval; COPD: Chronic obstructive pulmonary disease; CPT: Current procedural terminology; CVA: Cerebral vascular accident; EMR: Electronic medical records; FCl: Functional comorbidity index; IRR: Incidence rate ratio; NSQIP: National Surgical Quality Improvement Program; PR: Prevalence ratio; THA: Total hip arthroplasty; TKA: Total knee arthroplasty

\section{Acknowledgements}

Not applicable.

\section{Funding}

Funding for this study was provided by the Department of Orthopaedic Surgery, University of Michigan. No external funding was received.

\section{Availability of data and materials}

The datasets used and/or analysed during the current study are available from the corresponding author on reasonable request.

\section{Authors' contributions}

JG and HM conceived the study design, extracted data, performed all analyses, and wrote and edited the manuscript. PK extracted the data, performed some of the analyses, as well as edited the manuscript. All authors read and approved the final manuscript.

\section{Competing interests}

The authors declare that they have no competing interests.

\section{Consent for publication}

Not applicable.

Ethics approval and consent to participate

University of Michigan, study HUM00050086.

\section{Publisher's Note}

Springer Nature remains neutral with regard to jurisdictional claims in published maps and institutional affiliations.

\section{Author details}

${ }^{1}$ Department of Orthopaedic Surgery, University of Michigan, Ann Arbor, MI, USA. ${ }^{2}$ Department of Epidemiology, School of Public Health, University of Michigan, Ann Arbor, MI, USA. ${ }^{3}$ Department of Environmental Health Sciences, School of Public Health, University of Michigan, Ann Arbor, MI, USA. ${ }^{4}$ Department of Urology, Medical School, University of Michigan, Ann Arbor, MI, USA. ${ }^{5}$ School of Medicine, University of North Carolina, Chapel Hill, NC, USA.

Received: 15 December 2016 Accepted: 1 May 2017

Published online: 11 May 2017

\section{References}

1. Baker GR, Norton PG, Flintoft V, Blais R, Brown A, Cox J, Etchells E, Ghali WA Hebert P, Majumdar SR, O'Beirne M, Palacios-Derflingher L, Reid RJ, Sheps S, Tamblyn R. The Canadian Adverse Events Study: the incidence of adverse events among hospital patients in Canada. CMAJ. 2004:170:1678-86.

2. Brennan TA, Leape LL, Laird NM, Hebert L, Localio AR, Lawthers AG, Newhouse JP, Weiler PC, Hiatt HH, Harvard Medical Practice Study I. Incidence of adverse events and negligence in hospitalized patients: results of the Harvard Medical Practice Study I. 1991. Qual Saf Health Care 2004;13:145-51. discussion 51-2.

3. Davis P, Lay-Yee R, Briant R, Ali W, Scott A, Schug S. Adverse events in New Zealand public hospitals I: occurrence and impact. N Z Med J. 2002;115:U271.

4. Thomas EJ, Studdert DM, Burstin HR, Orav EJ, Zeena T, Williams EJ, Howard KM, Weiler PC, Brennan TA. Incidence and types of adverse events and negligent care in Utah and Colorado. Med Care. 2000;38:261-71.

5. Wilson RM, Runciman WB, Gibberd RW, Harrison BT, Newby L, Hamilton JD. The Quality in Australian Health Care Study. Med J Aust. 1995;163:458-71.

6. Christian CK, Gustafson ML, Roth EM, Sheridan TB, Gandhi TK, Dwyer K, Zinner MJ, Dierks MM. A prospective study of patient safety in the operating room. Surgery. 2006:139:159-73.

7. Dankelman J, Grimbergen CA. Systems approach to reduce errors in surgery. Surg Endosc. 2005:19:1017-21.

8. Leape LL, Brennan TA, Laird N, Lawthers AG, Localio AR, Barnes BA, Hebert $L$, Newhouse JP, Weiler PC, Hiatt $H$. The nature of adverse events in hospitalized patients. Results of the Harvard Medical Practice Study II. N Engl J Med. 1991;324:377-84.

9. Gawande AA, Thomas EJ, Zinner MJ, Brennan TA. The incidence and nature of surgical adverse events in Colorado and Utah in 1992. Surgery. 1999;126:66-75.

10. de Vries EN, Ramarattan MA, Smorenburg SM, et al. The incidence and nature of in-hopsital adverse events: A systematic review. Qual Saf Health Care. 2008;17:216-23. 
11. Catchpole K, Mishra A, Handa A, McCulloch P. Teamwork and error in the operating room: analysis of skills and roles. Ann Surg. 2008;247:699-70.

12. Lingard L, Espin S, Whyte S, Regehr G, Baker GR, Reznick R, Bohnen J, Orser B, Doran D, Grober E. Communication failures in the operating room: an observational classification of recurrent types and effects. Qual Saf Health Care. 2004;13:330-4.

13. World Alliance for Patient Safety. WHO guidelines for safe surgery. Geneva: World Health Organisation; 2008.

14. Haynes AB, Weiser TG, Berry WR, Lipsitz SR, Breizat AH, Dellinger EP, Herbosa T, Joseph S, Kibatala PL, Lapitan MC, Merry AF, Moorthy K, Reznick RK, Taylor B, Gawande AA, Safe Surgery Saves Lives Study Group. A Surgical Safety Checklist to reduce morbidity and mortality in a global population. N Engl J Med. 2009;360:491-9.

15. de Vries EN, Hollman MW, Smorenburg SM, Gouma DJ, Boermeester MA. Development and validation of the SURgical Patient Safety System (SURPASS) checklist. Qual Saf Health Care. 2009;18:121-6.

16. De VRies EN, Prins HA, Crolla R, et al. Effect of a comprehensive surgical safety system on patient outcomes. NEJM. 2010;363:1928-37.

17. Khuri SF, Daley J, Henderson W, Barbour G, Lowry P, Irvin G, Gibbs J, Grover F, Hammermeister K, Stremple JF, et al. The National Veterans Administration surgical risk study: risk adjustment for the comparative assessment of the quality of surgical care. J Am Coll Surg. 1995;180:519-31.

18. National Patient Safety Agency. Patient Safety Alert UPDATE. London: NPSA: 2009. http://www.npsa.nhs.uk/nrls/alerts-and-directives/alerts/safer-surgeryalert/. Accessed 5 Aug 2010.

19. Torholm C, Broeng L, Jorgensen PS, Bjerregaard $P$, Josephsen $L$, Jorgensen PK, Hagen K, Knudsen JB. Thromboprophylaxis by low-molecular weight heparin in elective hip surgery. A placebo controlled study. J Bone Joint Surg Br. 1991;73:434-8.

20. Pitto RP, Hamer H, Heiss-Dunlop W, Kuehle J. Mechanical prophylaxis of deep-vein thrombosis after total hip replacement: a randomised clinical trial. J Bone Joint Surg Br. 2004;86:639-42.

21. Warwick D, Friedman RJ, Agnelli G, Gil-Garay E, Johnson K, FitzGerald G, Turibio FM. Insufficient duration of venous thromboembolism prophylaxis after total hip or knee replacement when compared with the time course of thromboembolic events: findings from the Global Orthopaedic Registry. J Bone Joint Surg Br. 2007;89:799-807.

22. Blanco M, Clarke JR, Martindell D. Wrong site surgery near misses and actual occurrences. AORN J. 2009;90:215-22.

23. Reuther F. Avoidance of wrong site surgery. Experiences by the introduction of measures for quality control and patient safety in a surgical casualty hospital. Unfallchirurg. 2009;112:675-8.

24. Prokuski L. Prophylactic antibiotics in orthopaedic surgery. J Am Acad Orthop Surg. 2008;16:283-93.

25. Phillips JE, Crane TP, Noy M, Elliott TS, Grimer RJ. The incidence of deep prosthetic infections in a specialist orthopaedic hospital: a 15-year prospective survey. J Bone Joint Surg Br. 2006;88:943-8.

26. SooHoo NF, Lieberman JR, Ko CY, Zingmond DS. Factors predicting complication rates following total knee replacement. J Bone Joint Surg. 2006;88-A(3):480-5.

27. Pulido L, Ghanem $E$, Joshi A, Purtill JJ, Parvizi J. Periprosthetic joint infection: The incidence, timing, and predisposing factors. Clin Orthop. 2008;466:1710-5.

28. Stefansdottir A, Robertsson O, W-Dahl A, Kieman S, Gustafson P, Lidgren L. Inadequate timing of prophylactic antibiotics in orthopedic surgery. We can do better. Acta Orthop. 2009;80(6):633-8.

29. Schilling PL, Hallstrom BR, Birkmeyer JD, Carpenter JE. Prioritizing perioperative quality improvement in orthopaedic surgery. J Bone Joint Surg. 2010;92:1884-9.

30. Browne JA, Novicoff WM, D'Apuzzo MR. Medicaid payer status is associated with in-hospital morbidity and resource utilization following primary total joint arthroplasty. J Bone Joint Surg Am. 2014;96:e180.

31. Halamka JD, Osterland C, Safran C. CareWeb, a web-based medical record for an integrated health care delivery system. Int J Med Inform. 1999:54:1-8.

32. Charlson ME, Pompei P, Ales KL, MacKenzie CR. A new method of classifying prognostic comorbidity in longitudinal studies: Development and validation. J Chron Dis. 1987;40(5):373-83.

33. Groll DL, To T, Bombardier C, Wright JG. The development of a comorbidity index with physical function as an outcome. J Clin Epidemiol. 2005:58:595-602

34. Ouchterlony J, Arvidsson S, Sjostedt L, Svardsudd K. Perioperative and immediate postoperative adverse events in patients undergoing elective general and orthopaedic surgery. The Gothenburg study of perioperative risk (PROPER). Part II. Acta Anaesthesiol Scand. 1995;39:643-52.

35. Mahomed NN, Barrett J, Katz JN, Baron JA, Wright J, Losina E. Epidemiology of total knee replacement in the United States Medicare population. J Bone Joint Surg. 2005;87-A:1222-8

36. Wolf BR, Lu X, Li Y, Callaghan JJ, Cram P. Adverse outcome in hip arthroplasty: Long-term trends. J Bone Joint Surg. 2012;94:e103(1-8).

37. Carroll IR, Hah JM, Wang CKM, Gillespie MJ, Younger JW, Humphreys K, Goodman SB, Dirbas FM, Mackey SC. Pain duration and resolution following surgery: An inception cohort study. Pain Med. 2015;16:2386-96.

38. Hellsten EK, Hanbige MA, Manos AN, Lewis SJ, Massicotte EM, Fehlings MG, Coyte PC, Rampersaud YR. An economic evaluation of perioperative adverse events associated with spinal surgery. Spine J. 2013;13:44-53.

39. Sanhiyakumar V, Thakore RV, Greenberg SE, Whiting PS, Molina CS, Obremskey WT, Sethi MK. Adverse events in orthopaedics: Is trauma more risky? An analysis of the NSQIP data. J Orthop Trauma. 2015;29(7):337-41.

40. Koenig K, Huddleston Jl, Huddleston H, Maloney WJ, Goodman SB. Advanced age and comorbidity increase the risk for adverse events after revision total hip arthroplasty. J Arthroplasty. 2012;7:1402-7.

41. Minhas SV, Goyal P, Patel AA. What are the risk factors for cerebrovascular accidents after elective orthopaedic surgery? Clin Orthop Relat. 2015; Aug 20. [Epub ahead of print]

42. Huddleston JI, Maloney WJ, Wang Y, Verzier N, Hunt DR, Herdon JH. Adverse events across total knee arthroplasty: A national medicare study. Arthroplasty. 2009;24(6):95-100.

43. Quan H, Eastwood C, Cunningham CT, Liu M, Flemons W, De Coster C, Ghali WA, Imecchi investigators. Validity of AHRQ patient safety indicators derived from ICD-10 hospital discharge data (chart review study). BMJ Open. 2013;3:e003716

\section{Submit your next manuscript to BioMed Central and we will help you at every step:}

- We accept pre-submission inquiries

- Our selector tool helps you to find the most relevant journal

- We provide round the clock customer support

- Convenient online submission

- Thorough peer review

- Inclusion in PubMed and all major indexing services

- Maximum visibility for your research

Submit your manuscript at www.biomedcentral.com/submit 